\title{
Assessing the Productivity of Common Bean in Intercrop with Maize across Agro-Ecological Zones of Smallholder Farms in the Northern Highlands of Tanzania
}

\author{
Eliakira Kisetu Nassary ${ }^{1, * \mathbb{C}}$, Frederick Baijukya ${ }^{2}$ and Patrick Alois Ndakidemi ${ }^{1}$ \\ 1 School of Life Sciences and Bioengineering, The Nelson Mandela African Institution of Science and \\ Technology (NM-AIST), P.O. Box 447, Arusha, Tanzania; ndakidemipa@gmail.com \\ 2 International Institute of Tropical Agriculture (IITA), P.O. Box 34441 Dar es Salaam, Tanzania; \\ f.baijukya@cgiar.org \\ * Correspondence: keliakira@yahoo.com; Tel.: +255-784-734482
}

Received: 22 January 2020; Accepted: 26 February 2020; Published: 8 April 2020

\begin{abstract}
Common bean (Phaseolus vulgaris L.) is an important grain legume for food and cash of the smallholder farmers worldwide. However, the total potential benefits to be derived from the common bean as a source of food and income, its complementarities with non-legume food crops, and significance to the environment are underexploited. Intensification of common bean could provide approaches that offer new techniques to better manage and monitor globally complex systems of sustainable food production. Therefore, this study tried to assess the productivity of common bean bushy varieties when are involved as part of an intercrop with maize (Zea mays L.) in varying agro-ecological zones. The factors evaluated were the cropping seasons/years (S) (2015 and 2016), agro-ecological zones (A) above sea level (lower $843 \mathrm{~m}$, middle $1051 \mathrm{~m}$, upper $1743 \mathrm{~m}$ ), and cropping systems (C) (sole, intercrop). The data collected were the total biomass, number of pods per plant and seeds per pod, 100-seed weight as yield components, and grain yield. Bean and maize grain yields were used to calculate the partial $(\mathrm{P})$ and total land equivalent ratio (LER). Results indicated that the main effects of $\mathrm{S}, \mathrm{A}, \mathrm{C}$, and the interaction effects of $\mathrm{S} \times \mathrm{A}, \mathrm{S} \times \mathrm{C}, \mathrm{S} \times \mathrm{A} \times \mathrm{C}$ were significant on bean grain yields. Interactions of $\mathrm{S} \times \mathrm{A} \times \mathrm{C}$ were also significant on all measured variables. Results also indicated that continuous intercropping of bean with maize over two cropping seasons resulted in the increase of bean grain yields from 1.5 to $2.3 \mathrm{t} \mathrm{ha}^{-1}$ in the lower altitude, 2.0 to $2.3 \mathrm{t} \mathrm{ha}^{-1}$ in the middle altitude, and 1.8 to $2.9 \mathrm{t} \mathrm{ha}^{-1}$ in the upper altitude. Land utilization advantage of intercrops over monocultures yielded a total LER of 1.58, whereas the average partial land equivalent ratio (PLER) of individual beans was 1.53 .
\end{abstract}

Keywords: agricultural systems; food crops; smallholders; sustainable intensification

\section{Introduction}

Sustainable intensification of agricultural systems is important in the present and future world's food demand [1,2]. Intensification may increase food production, whereas sustainability ensures a continuous supply of food [3]. The increase in the world's population by 2050 is projected to be around 9.1 billion (34\% higher than today), and food production will need to increase by $70 \%[2,4]$. This projection indicates that more food is to be produced using less land, while other resources, including water and energy, will become the limiting factors [5]. There are still some promising advances in agricultural science and technology that have contributed to remarkable increases in food production, and the global agriculture growth is $2.5-3$ times over the last 50 years $[6,7]$. Further, the methods 
of global food production must change to minimize the impact on the environment and support the world's capacity to produce food in the future, including contribution to climate change, soil degradation, water scarcity, and destruction of biodiversity [8,9]. The impact of food production on the environment defines the land, methods deployed, and availability of water and soil resources, but there are trade-offs between environmental factors but without methods superior to others on ensuring environmental sustainability [10].

An increase in food production and availability without much impact on the environment is an important element of environmental sustainability [3,11,12]. The sustainable food system is composed of the environment, the people, and processes by which agricultural and farmed products are produced, processed, and brought to consumers without compromising the health of the ecosystems and vital cultures that provide food [13]. Farming systems in densely populated areas are defined by environments, altitude, precipitation during the crop growing season, latitude, and soil $\mathrm{pH}$ on one side, and biological significance to the crop species on the other [14-18]. Keba [19] indicated that environmental heterogeneity contributed much to the variations in crop performance and suggested a need for diverse environments in the evaluation of various crop genotypes. According to Tittonell et al. [20], the potential crop growth is site-specific, determined by variety and climate, but its actual yields are influenced by the interactions of local growth-limiting and reducing factors. Apart from other crops, grain legumes, such as common bean (Phaseolus vulgaris L.), peas (Pisum sativum L.), and pigeon pea (Cajanus cajan (L.) Millsp.), are commonly grown worldwide [21,22]. Other important grain legumes are groundnut (Arachis hypogaea L.), chickpea (Cicer arietinum L.), soybean (Glycine max L.), and cowpea (Vigna unguiculata L.) [23]. Depending on the cropping systems, the average grain yields of these crops are $0.5-1.5 \mathrm{t} \mathrm{ha}^{-1}$ [24-26] relative to the potential grain yield of $1.5-3.5 \mathrm{t} \mathrm{ha}^{-1}$ using varieties improved for high yielding $[18,26,27]$. Common bean fetches 2 to 2.5 times higher prices, on a weight basis than cereal crops like maize and, therefore, becomes an important component crop of maize intercrop [28,29] or as an understory in banana-coffee-based farming systems [30].

Common bean can improve soil fertility through the fixation of atmospheric nitrogen $\left(\mathrm{N}_{2}\right)$ in symbiosis with rhizobia $[31,32]$ and decomposition of its residues $[18,33]$. Under optimal conditions, common bean cultivation up to $72 \%$ of $\mathrm{N}$ derived from fixation has been obtained, and, in longer growing seasons, these are up to $125 \mathrm{~kg} \mathrm{~N} \mathrm{ha}^{-1}$ [31]. Nevertheless, farmers are aware of soil fertility improvement through affordable options, such as improved fallow, agroforestry, crop rotation, intercropping, and transfer of biomass [34,35]. Intercropping overcomes risks associated with the complete failure of one of the component crops [18,36]. The farmers' primary objective in maize and common bean intercropping is to optimize the productivity of maize, while a secondary objective is to produce good quality bean grain yields [37,38]. Intercropping aims to match efficient crop demands to the available growth resources and return from labor [39]. The advantages derived from intercrops arise from positive interactions in facilitation and complementarity as crops in mixtures differ in requirements and acquisition of water, light, and nutrients [40,41]. Common bean is a short duration crop (2.5-3 months), a characteristic that also permits its production during short rains [22,26]. Selection of compatible crops to be cultivated in mixtures and consideration of their sowing densities, time of introducing a legume crop in the system relative to the cereal crop, and demand for labor are important management approaches [39]. Sustainable intensification of rotations of food, cash, and $\mathrm{N}_{2}$-fixing grain legumes like a common bean with a non- $\mathrm{N}_{2}$-fixing staple and cash cereal crop like maize could provide approaches that offer new techniques to better manage and monitor globally complex systems of sustainable food production on smallholder farms. Therefore, this study summarized and interpreted results for the intercropping system in three different altitudes, whereas the other article from Nassary et al. [22] focused on describing the intercrop system and looking for the management options to further improve the system.

Rotational cultivations of cereals with grain legumes and/or cereals with the intercrops of cereals and grain legumes are important in contributing to the maintenance of soil health and $\mathrm{N}$ nutrition, as well as breaking the cycles of reducing factors, including insect pests, weeds, and diseases [18]. 
The same practice reduces the costs of crop production associated with the use of chemicals in controlling these reducing factors. Crop rotation reduces costs of equipment and peak labor requirements for field operations, increases interactions between the local community, and produces buffer market price fluctuations as they give direct sales [30]. Cereals and grain legumes sown in mixtures (diversification) and then rotated with pure cereals and/or grain legumes represent a sustainable intensification technology of improving food security for smallholder farmers [30]. The potential niche of grain legumes is wide due to their importance as a source of food and income, which is also displayed by the range of varieties and differences in their growth characteristics. The yields of grain legumes are often low, but their production is labor-intensive for sowing, plant management (fertilization, weeding, spraying), harvesting, threshing, and storage [22,30]. In terms of yield productivity and return from labor, farmers may find that rotation of grain legumes and cereals is not an attractive practice $[18,30]$. However, literature shows that the impact of grain legumes on the subsequent cereals is highly variable due to the effects of agro-ecologies, the status of the soil fertility, type and variety of the crop, and plant management options [18]. Therefore, assessing the benefits derived from rotations of different varieties of grain legumes with cereals will provide more grounds for the intensification and adoption of grain legumes than the continuous cultivation of cereals as an alternative technology for sustainable food production of smallholder farmers.

\section{Materials and Methods}

\subsection{Description of the Study}

This study was conducted in the northern highlands of Tanzania, and the experimental site is located between latitudes $02^{\circ} 30^{\prime}$ and $03^{\circ} 29^{\prime}$ and longitudes $30^{\circ} 30^{\prime}$ and $37^{\circ} 10^{\prime}$. The land-use types are diverse, including agriculture $(46 \%)$, grazing $(27 \%)$, forest $(14 \%)$, and mountain and snow land is $13 \%$ [42]. The larger (87\%) population of the region constitutes smallholders in farming and livestock husbandry (Figure 1). The climate is classified as Tropical Savannah, but it varies considerably because of the influence of the highest peak (5895 m) Mt. Kilimanjaro. Rainfall is bimodal, including a long rainy season, which starts in March and ends in June, and a short rainy season, which starts in October and ends in December [16,22,43].

The area is categorized in agro-ecological zones (AEZs) based on the altitude and the cropping patterns: (i) Higher zone lies between 1350-1800 m above sea level (a.s.l.) and receives annual rainfall of 1750-2000 mm; (ii) Middle zone lies between 900-1350 m a.s.l. and receives an average annual rainfall of 1250-1750 mm; (iii) Lower zone found below $900 \mathrm{~m}$ a.s.l. and receives an annual rainfall of 500-1250 mm [16]. In the area, the cropping systems and the AEZs still interact closely in terms of nutrients movement and run-off, and the soils are generally poor in fertility [16,22].

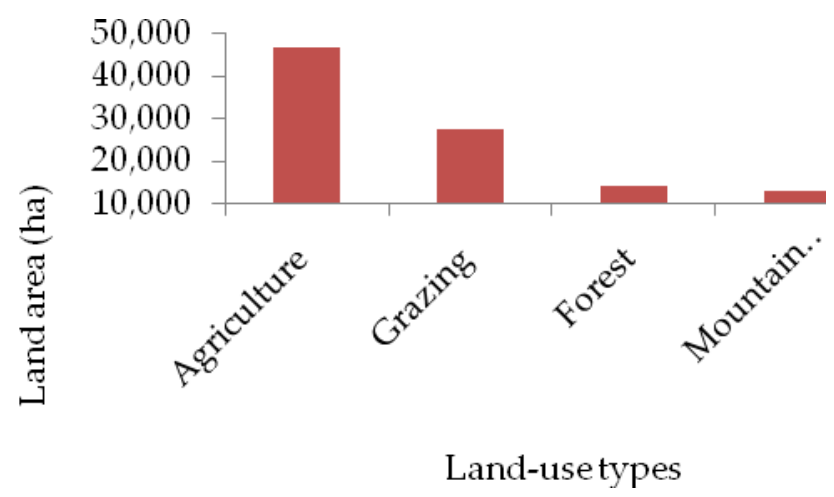

Figure 1. Land use types in the study areas. 


\subsection{Experimental Design and Treatments}

A randomized complete block design (RCBD) was used with fixed factors and treatments being: (1) cropping seasons (2015 and 2016); (2) agro-ecological zones: (i) lower, (ii) middle, and (iii) upper; cropping systems: (i) sole and (ii) intercropping. In each agro-ecological zone, there were five variants replicated four times, including sole maize, sole local bean, sole improved bean, intercrop of a local bean with maize, and intercrop of the improved bean with maize. The growing seasons were different according to the altitude, and the consecutive field trials were performed in the same fields, and no trial moved to a new field. Each plot was $5 \mathrm{~m} \times 3.2 \mathrm{~m}$ in size, with a path between plots of $1 \mathrm{~m}$. Hybrid maize seed Dekalb brands (DK 8031, DKC8053, DKC9089) were used. The three different varieties of maize used in the three regions are the brands marketed by agro-dealers as adapted to these particular agro-ecological zones.

Two bushy bean varieties (improved and local) were used throughout the period of experimentation. An intercrop was designed in such a way that it met various objectives: First, it should provide sufficient maize population since maize is the main staple food crop of the smallholder farmers. Second, it should allow sufficient opportunities for common bean to produce a reasonable yield to fix atmospheric $\mathrm{N}$ at its capacity and to produce sufficient residues for soil fertility improvement.

\subsection{Sowing, Spacing, and Harvesting}

Sowing was simultaneously for both maize and beans, but depending on the onset of rains of the cropping season in each agro-ecological zone AEZ. Likewise, harvesting of maize and beans differed due to the maturity cycle and within an altitude. In the lower zone, sowing of both maize and bean was at once on 29 March in 2015 and 6 April in 2016, whereas harvesting for bean was 2 July and 5 August for maize in 2015. In the same zone, harvesting of beans was on 16 July and 11 August for maize in 2016. In the middle zone, sowing during the 2015 season was on 26 March, and harvesting of bean and maize was on 18 June and 29 July, respectively. During the 2016 cropping season, in the same middle zone, sowing was on 5 April, but the harvesting of bean and maize was on 10 July and 17 August, respectively. In the upper zone, sowing during the 2015 season was on 3 September, and harvesting of bean and maize was on 6 December and 5 January, respectively. During the 2016 cropping season, in the same upper zone, sowing was on 1 September, and harvesting of bean and maize was on 10 December and 7 January, respectively. The overall mean monthly rainfall during the periods of plant growth in three agro-ecological zones is presented in Figure 2.

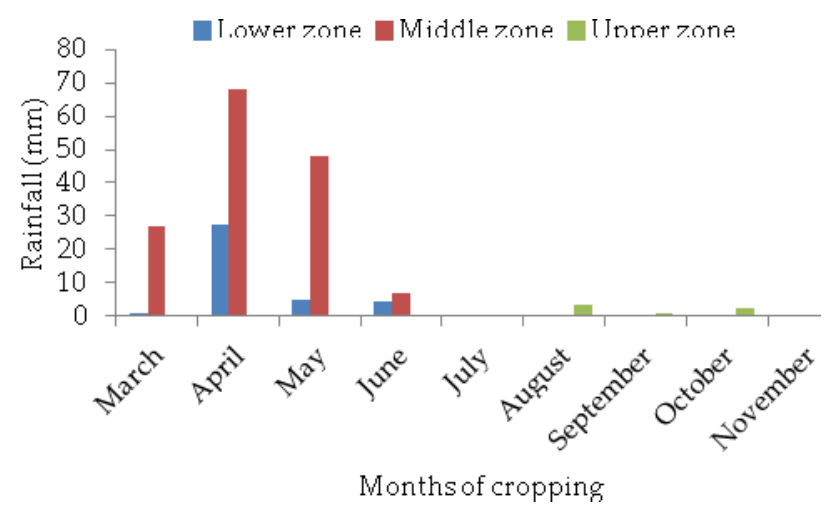

Figure 2. Mean monthly rainfall recorded on a daily basis (and averaged) during the periods of plant growth in three agro-ecological zones. The small mean monthly rains recorded in the upper zone (September to November) were expected since the sowing of crops in this zone is usually done during short rains due to excessive rains during long seasons experienced in from March to June. Crops in the upper zone benefit from residual moisture and spells of rains. 
Germination tests for both bean and maize seeds were above $98 \%$; so, two seeds were sown per hole and thinned to one seedling at 14 days after sowing, and the densities are as presented in Table 1. Fertilizer dozes were applied such that at sowing, triple superphosphate (TSP, $46 \% \mathrm{P}_{2} \mathrm{O}_{5}$ ) was applied in each planting hole at a rate of $25 \mathrm{~kg} \mathrm{P} \mathrm{ha}^{-1}$ based on the initial soil tests [22]. Further, fertilizer urea $(46 \% \mathrm{~N})$ was applied at a rate of $120 \mathrm{~kg} \mathrm{~N} \mathrm{ha}^{-1}$ to each maize plant 21 days after sowing [22,43].

Table 1. An indication of the sowing density of maize and common bean seeds.

\begin{tabular}{cccccccc}
\hline Crop & Cropping & $\begin{array}{c}\text { Sowing } \\
\text { Space } \mathbf{( c m )}\end{array}$ & Plants/Hole & Plants/Row & $\begin{array}{c}\text { No. } \\
\text { Rows/Plot }\end{array}$ & Plants/Plot & $\begin{array}{c}\text { Plants/ha } \\
\text { equiv. }\end{array}$ \\
\hline Maize & Sole & $80 \times 30$ & 1 & 17 & 5 & 85 & 41,666 \\
Maize & Intercrop & $80 \times 30$ & 1 & 17 & 5 & 85 & 41,666 \\
Bean & Sole & $40 \times 10$ & 1 & 51 & 9 & 459 & 286,875 \\
Bean & Intercrop & $80 \times 10$ & 1 & 51 & 4 & 204 & 127,500 \\
\hline
\end{tabular}

\subsection{Data Collection}

Plants of the inner rows in each plot were identified and tagged with blue-colored strings for the measurements. In sole bean, only plants in the inner seven rows (total of 35 plants) were randomly selected, and the measurements were taken. In bean intercropped with maize, plants from two innermost rows (total of 15 plants) were randomly selected for the measurements. In maize, eleven plants from the inner three rows were identified and used for the study of dried grain yield and in the calculation of land equivalent ratio (LER) with the bean. Only results of the cropping systems (sole and intercrops) in each agro-ecological zone were involved in the determination of LER as the pooled means of the two cropping seasons (2015 and 2016). At harvest of the bean, plants were harvested by cutting at the ground level and weighed for the total weight determination, then threshed, and grains were weighed for dry grain yield determination. Of the harvested plants, ten plants (among the same used for other measurements) were randomly selected, and counting of pods was done in each plant before threshing for determination of the number of seeds. Data collection in maize at harvest followed the same procedures as for common bean with few modifications.

\subsection{Statistical Analysis}

The fixed main effects were the cropping seasons, agro-ecological zones, and cropping systems, whereas replicate blocks were treated as the random effect. The interactions of these factors were also tested. The effects of significant treatments were isolated by a posthoc Tukey's-HSD test at a threshold of $5 \%$. The land utilization advantages of common bean in maize mixtures were compared by the land equivalent ratios (LERs), with PLER being the partial LERs of maize or common [44]:

$$
\mathrm{LER}=\mathrm{PLER}_{\text {maize }}+\mathrm{PLER}_{\text {common bean }}
$$

where,

$$
\begin{aligned}
\text { PLER }_{\text {maize }} & =\frac{\text { Yield of maize in intercrop }}{\text { Yield of maize in monoculture }} \\
\mathrm{PLER}_{\text {common bean }} & =\frac{\text { Yield of common bean in intercrop }}{\text { Yield of common bean in monoculture }}
\end{aligned}
$$

\section{Results}

\subsection{Effects of Cropping Seasons, Agro-Ecological Zones, and Cropping Systems on Bean Performance}

The main effects of the cropping seasons and variations of agro-ecological zones were only significant on the number of pods per bean plant but not on other measured variables. On the other hand, the main effect of cropping systems was significant on the measured bean grain yield and the attributes of yield. The significantly larger bean grain yields $\left(2.9\right.$ to $\left.3.0 \mathrm{tha}^{-1}\right)$ were obtained in 
monoculture bean compared with grain yields ( 1.9 to $\left.2.1 \mathrm{t} \mathrm{ha}^{-1}\right)$ obtained in beans intercropped with maize. Results also indicated that total biomass followed a similar trend of grain yield where the significantly larger biomass yield ( 5.5 to $7.4 \mathrm{t} \mathrm{ha}^{-1}$ ) was obtained in monoculture beans relative to the biomass yield (4.3 to $5.0 \mathrm{t} \mathrm{ha}^{-1}$ ) obtained in beans intercropped with maize (Table 2).

The main interaction effects between cropping seasons and agro-ecological zones, cropping seasons and cropping systems, and the interactions among cropping seasons, agro-ecologies, and cropping systems were significant on bean grain yield. Results showed that continuous intercropping of a local bean with maize over two cropping seasons (2015 and 2016) resulted in the increase of bean grain yields by $53 \%$ (1.5 to $\left.2.3 \mathrm{t} \mathrm{ha}^{-1}\right)$ in the lower altitude, $15 \%\left(2.0\right.$ to $\left.2.3 \mathrm{t} \mathrm{ha}^{-1}\right)$ in the middle altitude, and $61 \%$ (1.8 to $\left.2.9 \mathrm{t} \mathrm{ha}^{-1}\right)$ in the upper altitude. Also, intercrops of the improved bean with maize had grain yield advantage of $162 \%$ and $52 \%$ in the lower and upper altitudes but with a yield drop by $86 \%$ in the middle altitude (Figure 3). The interactions of cropping seasons and agro-ecological zones were also significant on other measured variables except for the number of seeds recorded in a pod. Further, the interaction effects between cropping seasons and cropping systems on one side and between agro-ecological zones and cropping systems on the other were significant on the number of pods per bean plant and 100-seed weight. Also, results indicated that the interactions of cropping seasons, agro-ecological zones, and cropping systems were significant on all measured variables (Table 2). 
Table 2. Grain yields, total biomass, number of pods per bean plant, number of seeds per pod, and weight of 100 -seeds of the common bean as affected by the cropping seasons, agro-ecological zones, cropping systems, and their interactions.

\begin{tabular}{|c|c|c|c|c|c|c|}
\hline \multirow[t]{2}{*}{ Factors } & \multirow[t]{2}{*}{ Sub-Factors } & \multicolumn{5}{|c|}{ Measured Variables in Common Bean } \\
\hline & & Grain Yield (t ha $\left.{ }^{-1}\right)$ & Biomass (t ha $\left.{ }^{-1}\right)$ & Pods per plant & Seeds per pod & 100 -seed wt (g) \\
\hline \multirow[t]{2}{*}{ Seasons/years (S) } & 2015 & 2.45 & 5.52 & $12 \mathrm{a}$ & 3 & 37.31 \\
\hline & 2016 & 2.54 & 5.63 & $9 b$ & 2 & 33.28 \\
\hline \multirow[t]{3}{*}{ Agro-ecological zones (A) } & Lower agro-zone & 2.22 & 4.82 & $6 b$ & $3 a b$ & 33.01 \\
\hline & Middle agro-zone & 2.64 & 6.27 & $7 \mathrm{~b}$ & $3 a b$ & 37.78 \\
\hline & Upper agro-zone & 2.63 & 5.63 & $12 \mathrm{a}$ & $2 b$ & 35.09 \\
\hline \multirow[t]{4}{*}{ Cropping systems (C) } & Monoculture local bean & $2.97 \mathrm{a}$ & $7.44 a$ & $13 a$ & 3a & $25.83 \mathrm{c}$ \\
\hline & Monoculture improved bean & $2.94 a$ & $5.54 \mathrm{ab}$ & $5 c$ & $2 b$ & $49.66 \mathrm{a}$ \\
\hline & Intercropped local bean & $2.13 b$ & $4.98 \mathrm{~b}$ & $10 \mathrm{~b}$ & $3 a$ & $23.52 \mathrm{c}$ \\
\hline & Intercropped improved bean & $1.94 \mathrm{~b}$ & $4.34 \mathrm{~b}$ & $5 c$ & $2 b$ & $42.16 \mathrm{~b}$ \\
\hline \multicolumn{7}{|l|}{ 3-WAY ANOVA (F-stat.) } \\
\hline $\mathrm{S}$ & & $0.16(P=0.717)$ & $0.04(P=0.858)$ & $126.14(P=0.002)$ & $0.001(P=0.976)$ & $7.65(P=0.070)$ \\
\hline $\mathrm{A}$ & & $1.73(P=0.219)$ & $1.00(P=0.395)$ & $22.75(P<001)$ & $3.90(P=0.050)$ & $2.45(P=0.128)$ \\
\hline $\mathrm{C}$ & & $12.19(P<001)$ & $5.77(P=0.002)$ & $31.23(P<001)$ & $5.00(P=0.004)$ & $70.14(P<001)$ \\
\hline $\mathrm{S} \times \mathrm{A}$ & & $11.12(P=0.002)$ & $10.97(P=0.002)$ & $37.15(P<001)$ & $0.87(P=0.443)$ & $6.96(P=0.010)$ \\
\hline $\mathrm{S} \times \mathrm{C}$ & & $3.64(P=0.018)$ & $1.80(P=0.159)$ & $6.02(P=0.001)$ & $0.96(P=0.417)$ & $3.17(P=0.031)$ \\
\hline $\mathrm{A} \times \mathrm{C}$ & & $1.33(P=0.261)$ & $0.93(P=0.481)$ & $3.97(P=0.002)$ & $1.91(P=0.095)$ & $2.98(P=0.014)$ \\
\hline $\mathrm{S} \times \mathrm{A} \times \mathrm{C}$ & & $4.11(P=0.002)$ & $2.58(P=0.028)$ & $5.51(P=0.002)$ & $2.49(P=0.034)$ & $3.61(P=0.004)$ \\
\hline
\end{tabular}

Means in a column for each of the measured variables bearing different letter(s) differ significantly. 
In the lower zone, a significant relationship in improved bean variety when intercropped with maize was between the number of pods per bean plant and the total biomass $(r=0.71 ; P=0.0485)$. In the middle zone, the significant relationships were between total biomass and 100-seed weight $(r=0.78 ; P=0.0212)$ and with the number of pods per plant $(r=0.83 ; P=0.0131)$ in improved bean when intercropped with maize. Improved bean intercropped with maize in the upper zone recorded a significant relationship between bean grain yield and total biomass $(r=0.80 ; P=0.0166)$. On the other hand, the local bean variety, when intercropped with maize in the middle zone, had significant relationships between bean grain yield and the number of pods per bean plant $(r=0.78 ; P=0.0223)$. In the upper zone, the local bean intercropped with maize indicated a significant relationship between total biomass and bean grain yield $(r=0.75 ; P=0.0300)$ and the number of pods per bean plant $(r=0.81 ; P=0.0155)$.

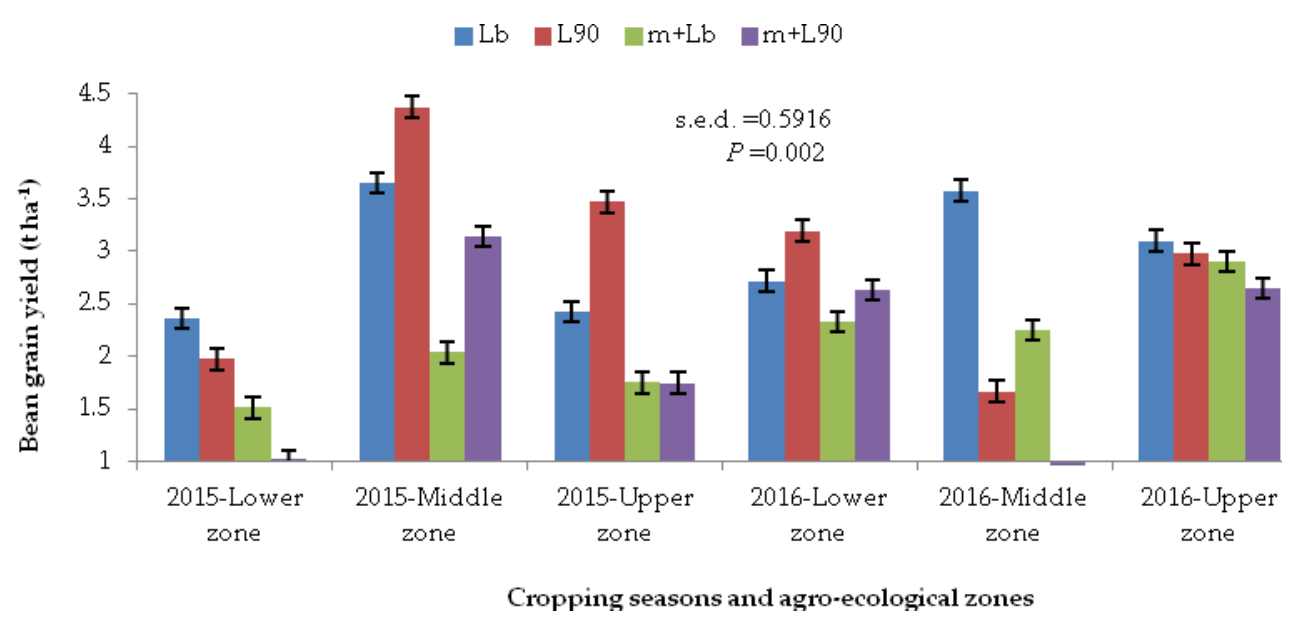

Figure 3. Bean grain yield as significantly affected by the interactions of cropping seasons $\times$ agro-ecologies $\times$ cropping systems. Key: $\mathrm{Lb}=$ monoculture local bean, $\mathrm{L} 90=$ monoculture improved bean, $\mathrm{m}+\mathrm{Lb}=$ intercropped local bean with maize, $\mathrm{m}+\mathrm{L} 90=$ intercropped improved bean with maize, s.e.d. $=$ standard errors of differences of means.

\subsection{Land Utilization Advantages of Intercropping Common Bean with Maize}

Partial and total land equivalent ratios (LER) were used to assess the land utilization advantages as one of the benefits derived using intercrops of bushy varieties of common bean with maize on smallholder farms based on the varying agro-ecological zones. The partial land equivalent ratio of beans (PLER-bean) was significantly affected by the variation in agro-ecological zones $(P=0.040)$ and by the differences in common bean varieties used $(P=0.039)$ when were intercropped with maize. There was no significant interaction effect of agro-ecological zones and common bean varieties on the PLER-bean (Table 3). The partial land equivalent ratio of maize (PLER-maize) and the total LER of intercropped bean and maize were not significantly affected by the agro-ecological zones, common bean varieties, and/or their interactions. Intercrops of the local bean with maize produced larger total LER (1.57) than the intercrops of improved bean with maize (1.48), which averaged to a PLER of 1.53 (Table 3). Table 4 presents grain yields of maize as affected by agro-ecological zones, seasons of cropping in years, systems of cropping with the bean, and the interactions of these factors. The cropping systems-related yield data was used in the calculation of the LER. 
Table 3. Partial and total land equivalent ratios (PLER and LER) of maize and two varieties of common bean measured in different agro-ecological zones.

\begin{tabular}{|c|c|c|c|c|c|}
\hline \multirow[t]{2}{*}{ Factors } & \multirow[t]{2}{*}{ Treatments } & & \multicolumn{3}{|c|}{ Measured Variables in Common Bean } \\
\hline & & & PLER-bean & PLER-m & LER-Total \\
\hline \multirow[t]{6}{*}{ Agro-ecological zones (A) } & Lower zone & & $0.67 \mathrm{a}$ & $0.72 \mathrm{a}$ & $1.38 \mathrm{a}$ \\
\hline & Middle zone & & $0.80 \mathrm{ab}$ & $0.78 \mathrm{a}$ & $1.58 \mathrm{a}$ \\
\hline & Upper zone & & $0.84 \mathrm{~b}$ & $0.76 \mathrm{a}$ & $1.61 \mathrm{a}$ \\
\hline & & S.E.D. & 0.054 & 0.09 & 0.12 \\
\hline & & $p$-value & 0.040 & 0.793 & 0.21 \\
\hline & & $\mathrm{CV}(\%)$ & 9.9 & 17.4 & 11.1 \\
\hline \multirow[t]{5}{*}{ Bean varieties (V) } & Improved bean & & $0.73 a$ & $0.75 \mathrm{a}$ & $1.48 \mathrm{a}$ \\
\hline & Local bean & & $0.81 \mathrm{~b}$ & $0.76 a$ & $1.57 \mathrm{a}$ \\
\hline & & S.E.D. & 0.0368 & 0.08 & 0.08 \\
\hline & & p-value & 0.039 & 0.998 & 0.297 \\
\hline & & $\mathrm{CV}(\%)$ & 5.6 & 14.5 & 5.8 \\
\hline \multicolumn{6}{|l|}{2 -WAY ANOVA (F-stat.) } \\
\hline $\mathrm{A}$ & & & $5.77^{*}$ & $0.24 \mathrm{~ns}$ & $2.05 \mathrm{~ns}$ \\
\hline $\mathrm{V}$ & & & $5.86^{*}$ & $0.001 \mathrm{~ns}$ & $1.23 \mathrm{~ns}$ \\
\hline $\mathrm{A} \times \mathrm{V}$ & & & $0.44 \mathrm{~ns}$ & $2.05 \mathrm{~ns}$ & $2.6 \mathrm{~ns}$ \\
\hline
\end{tabular}

Key: LER is the land equivalent ratio, and PLER-bean and PLER-m are partial LER of beans and maize, respectively; S.E.D. $=$ standard errors of differences of means; $\mathrm{CV}=$ coefficient of variation. Means in a column for each measured LER bearing different letter(s) for each assessed treatment in a specific category of factors differ significantly; * and ns are $<0.05$ and not significant, respectively.

Table 4. Maize grain yields (in $\mathrm{t} \mathrm{ha}^{-1}$ ) recorded over two cropping seasons (2015 and 2016) as affected by the agro-ecological zones, cropping seasons (in years), cropping systems with beans, and the interactions of these factors.

\begin{tabular}{|c|c|c|c|c|c|c|c|c|}
\hline \multirow{2}{*}{$\begin{array}{c}\text { Factors } \\
\text { A: }\end{array}$} & \multicolumn{3}{|c|}{ Treatments and Yield Values } & \multicolumn{5}{|c|}{ Statistical Parameters } \\
\hline & Lower & Middle & Upper & & S.E.D. & F. Stat. & p-value & \\
\hline \multirow{4}{*}{ S: } & $1.4 \mathrm{c}$ & $1.8 \mathrm{~b}$ & $2.5 \mathrm{a}$ & & 0.11 & $54.63 * * *$ & $<0.001$ & \\
\hline & & & & & & & & \\
\hline & 2015 & 2016 & & & S.E.D. & F. Stat. & p-value & \\
\hline & 2.1 & 1.8 & & & 0.13 & $3.77 \mathrm{~ns}$ & 0.084 & \\
\hline \multicolumn{9}{|l|}{ C: } \\
\hline & $m+L 90$ & $\mathrm{~m}+\mathrm{Lb}$ & Sole & & S.E.D. & F. Stat. & p-value & \\
\hline \multirow[b]{2}{*}{$A \times S:$} & 1.7 & 1.9 & 2.2 & & 0.21 & $2.57 \mathrm{~ns}$ & 0.09 & \\
\hline & Lower & Middle & Upper & & S.E.D. & F. Stat. & p-value & \\
\hline 2015 & $1.4 \mathrm{~b}$ & $2.4 a$ & $2.3 a$ & & 0.19 & $13.06^{* *}$ & 0.002 & \\
\hline 2016 & $1.4 \mathrm{~b}$ & $1.2 \mathrm{~b}$ & $2.7 \mathrm{a}$ & & & & & \\
\hline \multicolumn{9}{|l|}{$A \times C:$} \\
\hline & Lower & Middle & Upper & & S.E.D. & F. Stat. & p-value & \\
\hline Sole & $1.6 \mathrm{bc}$ & $2.1 \mathrm{a}-\mathrm{c}$ & $2.9 \mathrm{a}$ & & 0.32 & $0.42 \mathrm{~ns}$ & 0.793 & \\
\hline $\mathrm{m}+\mathrm{Lb}$ & $1.6 \mathrm{bc}$ & $1.7 \mathrm{bc}$ & $2.3 \mathrm{ab}$ & & & & & \\
\hline \multirow{2}{*}{$\begin{array}{c}\text { m + L90 } \\
\mathbf{S} \times \mathbf{C}:\end{array}$} & $1.1 \mathrm{c}$ & $1.7 \mathrm{bc}$ & $2.4 \mathrm{ab}$ & & & & & \\
\hline & Sole & $\mathrm{m}+\mathrm{Lb}$ & $m+L 90$ & & S.E.D. & F. Stat. & p-value & \\
\hline 2015 & 2.1ab & $2.0 \mathrm{ab}$ & 2.1ab & & 0.2747 & $2.51 \mathrm{~ns}$ & 0.095 & \\
\hline 2016 & $2.3 a$ & $1.7 \mathrm{ab}$ & $1.4 \mathrm{~b}$ & & & & & \\
\hline \multicolumn{9}{|l|}{$A \times S \times C:$} \\
\hline \multirow[t]{2}{*}{ Zone } & & & 2015 & & & & 2016 & \\
\hline & & $m+L 90$ & $\mathrm{~m}+\mathrm{Lb}$ & Sole & & $m+L 90$ & $\mathrm{~m}+\mathrm{Lb}$ & Sole \\
\hline Lower & & $1.1 \mathrm{c}$ & $1.6 b c$ & $1.6 \mathrm{bc}$ & & 1.1c & $1.6 b c$ & $1.6 \mathrm{bc}$ \\
\hline Middle & & $2.4 a-c$ & $2.3 a-c$ & $2.6 a-c$ & & $1.0 \mathrm{c}$ & $1.2 \mathrm{bc}$ & $1.5 b c$ \\
\hline Upper & & $2.8 \mathrm{ab}$ & $2.1 \mathrm{a}-\mathrm{c}$ & $2.1 \mathrm{a}-\mathrm{c}$ & & $2.0 \mathrm{bc}$ & $2.5 a-c$ & $3.7 \mathrm{a}$ \\
\hline
\end{tabular}

Maize grain yields were significantly affected by the variation in agro-ecological zones and the interactions of agro-ecological zones and the cropping seasons. Key: $\mathrm{m}+\mathrm{L} 90=$ maize intercropped with the improved bean variety Lyamungu 90; $\mathrm{m}+\mathrm{Lb}=$ maize intercropped with the local bean variety Mkanamna; S.E.D. $=$ standard errors of the differences of means; $\mathrm{A}=$ agro-ecological zones; $\mathrm{S}=$ seasons of cropping (2015 and 2016); $\mathrm{C}=$ cropping systems (monoculture or intercropping); ns = not significant. ${ }^{* *}$ means $0.00<p \leq 0.01 ;{ }^{* * *}$ means $p<0.001$. 


\section{Discussion}

\subsection{Performance of Common Bean}

The present study provided a better insight that seasons of the year, altitudes, and cropping systems were the important elements in improving the productivity of common bean in intercrops with maize on smallholder farms with land shortages. This was supported by the main effects of the cropping seasons and agro-ecological zones on the production of many pods per bean plant as this had an implication on the seeds formed and the resultant grain yield. The main effects of cropping systems were realized on all measured variables related to yield and grain yield itself. The significantly larger bean grain yields (2.9-3.0 $\left.\mathrm{tha}^{-1}\right)$ obtained in monoculture beans relative to grain yields $\left(1.9-2.1 \mathrm{t} \mathrm{ha}^{-1}\right)$ obtained in beans intercropped with maize signified the importance of cropping systems on the overall productivity of common bean.

Interactions of the cropping seasons with the agro-ecological zones and cropping systems were significant on bean grain yield. Exceptions of the interaction effects on bean grain yields were observed between agro-ecological zones and cropping systems, probably due to the lack of the element of cropping seasons. The increase in bean grain yields in intercrops with maize over two cropping seasons (2015 and 2016) suggested yield advantage derived from these intercrops, which could be attributed to the complementarities of growth resources between the bean and maize plants. It was also likely that there were additional nutrients and improvement of soil quality between the two cropping seasons during off-seasons. This finding showed the implication of cropping systems on the productivity of common bean when intercropped with maize [22]. Intercropping common bean with maize could also be a useful tool in breeding improvement for environmental adaptability due to associated competitions on one side and niche complementarity on the other [45].

The low bean grain yields obtained in intercrops in the lower and upper zones could be attributed, probably, to the stiff competition encountered by bean plants from maize plants. Also, rainfall in the lower zone was little and poorly distributed due to the short cycle, hence induced higher inter-specific competitions between crops in mixtures. The upper zone is relatively cool due to higher altitude with closer proximity to the forest belt, which probably retarded bean plants in intercrops with maize. These arguments were similar to the findings of a study conducted by Matusso et al. [46], who showed that crops with $\mathrm{C} 4$ photosynthetic characteristics, like maize, were competitively dominant in the system when intercropped with C3 species, like the common bean. Low performance of common bean in intercrop with maize could also be associated with the short root system of beans and their shallow distributions, which probably reduced competitive advantage for the growth factors, such as light, nutrients, water, and space [47,48]. According to Mekbib [49], common bean production is determined by the interactions of environments and the cropping systems employed. The number of pods produced by individual bean plant has implications on the grains formed and yield, and the cropping systems should be a critical factor to consider in each agro-ecological zone. It is also likely that common bean in an intercrop with maize creates good niche complementarity between each other for water, light, and nutrients, such as $\mathrm{N}$-fixed, phytoavailability of $\mathrm{P}$ from phosphatases, and solubility of micronutrients, including iron (Fe), zinc $(\mathrm{Zn})$, manganese $(\mathrm{Mn})$, and copper $(\mathrm{Cu})[50,51]$.

The performance of common bean is not significantly influenced by the cropping seasons $\times$ agro-ecologies $\times$ cropping systems interactions, deviating from Keba [19], which might be explained by the differences in these factors [26]. According to Atuahene-Amankwa et al. [52], evidence of bean varieties and cropping system interactions indicates the advantages of interactions by selecting compatible intercrops. Consistent with the findings of the present study, Mebrahtu et al. [53] found that bean genotypes and management interactions were significant on grain yields of legumes. The inherent soil properties, agronomic practices, decisions of farmers to allocate resources or combinations of these have been among the drivers of the variability of crop performance [26]. 


\subsection{Land Utilization Advantage of Common Bean Intercrop with Maize}

There is variability in relationships of the critical variables considered in identifying the productivity of bean and maize intercrops in each agro-ecological zone. Comparing three agro-ecological zones, an intercrop of common bean with maize is best suited in the lower and middle zones, and this could be explained by the growth and branching habit, as well as the nature of canopy architecture of the studied bush beans [22]. Studies conducted by Atuahene-Amankwa et al. [52] and Woolley and Rodriguez [54] indicated that positive relationships between common bean grain yields sown in intercrop with cereals could predict the performance of the bean crop and the overall system productivity.

The variation in agro-ecological zones and differences in common bean varieties used as component crops to maize were significant on the PLER of bean with the larger PLER-bean recorded in the middle and upper agro-ecological zones but not in the lower zone. This finding could be attributed to the increase in organic matter and nutrients pool in the middle and upper zones compared with the lower zone where livestock grazing is by nomadic pastoralist [16,42]. Further, the larger total LER (1.58) was obtained in the middle zone, indicating better land utilization advantage over other zones. The significant PLER of beans as the main effect of the variation in bean varieties could be attributed to the differences in grain yields between these varieties. The two bean varieties used in the present study also substantiated the significance of this finding as their individual total LERs ranged from 1.48 to 1.57. Also, the land utilization advantage derived from intercrops of these bean varieties with maize could be attributed to their competitive advantages over the effects associated with a component maize crop for light, nutrients, and water [22,26,55]. These beans also add more residues and nutrients in the soil after decomposition as they shed most of their leaves on the ground at senescence. The LER obtained in the present study involving intercrops with common bean and maize was greater than 1.36 obtained by Alemayehu et al. [56] in simultaneously sown intercrops of maize and common bean. Saban et al. [57] also reported LER greater than 1 with intercrops of bean and maize. Alemayehu et al. [56] found that the interaction of cropping and different varieties of common bean had no significant effect on LER, similar to the findings of the present study. The LERs greater than 1 in all intercrops show advantages derived from land utilization efficiency of intercropping common bean with maize over sole cropping of each crop. These findings suggested that more lands would be required in the monoculture of either of the component crops to produce the same yield obtained from their intercropping [44]. The higher planting density of $\sim 42,000$ plants/ha adopted in the present study was similar to what farmers use when growing maize in these areas. However, farmers often sow two plants per hole at a spacing of $60 \mathrm{~cm}$ in a row and $80 \mathrm{~cm}$ between rows instead of a single plant spaced $30 \mathrm{~cm}$ from another in a row. This causes competition between the maize plants, and the same plants might have competition from the companion bean plant. Similar competitions due to planting densities might have affected the yields of both maize and bean crops that might lessen the impact of intercropping. Also, this may render farmers not to use intercropping due to reduction in maize yields (a prioritized staple and revenue crop), and the practice increases labor demands for planting and harvesting of crops in intercrops [18]. Based on the findings of a review synthesized by Nassary et al. [18], the findings of the present study would also be translated to other (similar) regions. However, the overall increase in total yield and the return from labor due to field operations under similar settings remain to be an area of further investigation.

\section{Conclusions}

In the present article, we summarized the results of two years of field experiments at sites differing in altitude and, therefore, in soils, rainfall amount and distribution, temperature, and other environmental effects. The growth of three maize varieties, two bean varieties, and intercrop systems with maize and bean were tested for yield and yield components. The productivity of a common bean was importantly determined by the main effects of cropping seasons, agro-ecological zones, and well designed bean-maize mixtures relative to bean monoculture. The performance of the beans with maize intercrop was very good, probably, taking into consideration that the number of bean plants was only 
$50 \%$ compared to the bean field plus maize, where there is some competition from the maize plants. This study showed high variability of yields between years plus the almost total failure of the beans in intercrop systems in 2015 in the lower zone and 2016 in the middle zone. The strong variability in yields between years is a more important focus concerning the reliable food supply and income of smallholder farms. However, in order to be able to recommend an intercrop system for a certain altitude, some more trials and more years of experience would be very valuable.

Author Contributions: Conceptualization, P.A.N., F.B., and E.K.N.; methodology, P.A.N., F.B., and E.K.N.; software, E.K.N.; validation, P.A.N., F.B., and E.K.N.; formal analysis, E.K.N.; investigation, P.A.N., F.B., and E.K.N.; resources, P.A.N. and E.K.N.; data collection and analysis, E.K.N.; writing-original draft preparation, P.A.N., F.B., and E.K.N.; writing-review and editing, P.A.N. and F.B.; visualization, P.A.N. and F.B.; supervision, P.A.N. and F.B.; project administration, P.A.N. and F.B.; funding acquisition, P.A.N. and F.B. All authors have read and agreed to the published version of the manuscript.

Funding: This research was funded by the Bill \& Melinda Gates Foundation through N2Africa Project: Putting Nitrogen Fixation to Work for Smallholder Farmers in Africa (www.N2Africa.org), a grant to Wageningen University and Research, the Netherlands and the International Institute of Tropical Agriculture (IITA) through the Graduate Research Internship.

Acknowledgments: Author Eliakira Kisetu Nassary is grateful to supervisors, Frederick Baijukya and Patrick Alois Ndakidemi, for their guidance through series of constructive criticisms and field experimentations for which the output of this work is put in place as a manuscript.

Conflicts of Interest: The authors declare that the submitted work was carried out in the absence of any personal, professional, or financial relationships that could potentially be construed as a conflict of interest.

\section{References}

1. Raimi, A.; Adeleke, R.; Roopnarain, A. Soil fertility challenges and biofertiliser as a viable alternative for increasing smallholder farmer crop productivity in sub-Saharan Africa. Cogent Food Agric. 2017, 3, 1400933. [CrossRef]

2. Loboguerrero, A.M.; Campbell, B.M.; Cooper, P.J.M.; Hansen, J.W.; Rosenstock, T.; Wollenberg, E. Food and earth systems, priorities for climate change adaptation and mitigation for agriculture and food systems. Sustainability 2019, 11, 1372. [CrossRef]

3. Pretty, J.; Toulmin, C.; Williams, S. Sustainable intensification in African agriculture. Int. J. Agric. Sustain. 2011, 9, 5-24. [CrossRef]

4. Stagnari, F.; Maggio, A.; Galieni, A.; Pisante, M. Multiple benefits of legumes for agriculture sustainability, an overview. Chem. Biol. Technol. Agric. 2017, 4, 2. [CrossRef]

5. FAO (Food and Agriculture Organization). How to Feed the World in 2050; FAO: Rome, Italy, 2009.

6. FAO (Food and Agricultural Organization). The State of the World's Land and Water Resources for Food and Agriculture, Managing Systems at Risk; FAO: Rome, Italy; Earthscan: London, UK, 2011.

7. Christou, P.; Savin, R.; Costa-Pierce, B.; Misztal, I.; Whitelaw, B. Sustainable Food Production; Springer: New York, NY, USA, 2013; ISBN 978-1-4614-5796-1.

8. Foresight. The Future of Food and Farming, Challenges and Choices for Global Sustainability. Final Project Report; Government Office for Science: London, UK, 2011.

9. Food Chain Evaluation Consortium. Scoping Study. Delivering on EU Food Safety and Nutrition in 2050-Scenarios of Future Change and Policy Responses; European Commission: Brussels, Belgium, 2014.

10. FAO (Food and Agriculture Organization). Building a Common Vision for Sustainable Food and Agriculture, Principles and Approaches; FAO: Rome, Italy, 2014.

11. Foley, J.A.; Ramankutty, N.; Brauman, K.A.; Cassidy, E.S.; Gerber, J.S.; Johnston, M.; Zaks, D.P.M. Solutions for a cultivated planet. Nature 2011, 478, 337-342. [CrossRef] [PubMed]

12. Vanlauwe, B.; Bationo, A.; Chianu, J.; Giller, K.E.; Merckx, R.; Mokwunye, U.; Ohiokpehai, O.; Pypers, P.; Tabo, R.; Shepherd, K.; et al. Integrated soil fertility management, Operational definition and consequences for implementation and dissemination. Outlook Agric. 2011, 39, 17-24. [CrossRef]

13. FAO (Food and Agricultural Organization). Introduction to Sustainable Food Systems and Value Chains. 2016. Available online: http://www.fao.org/sustainable-food-value-chain/www.fao.org/about/what-we-do/so4 (accessed on 13 October 2019). 
14. Abera, T.; Tana, T.; Pant, L.M. Grain and LER of maize bean intercropping as affected by inorganic and organic fertilizers and population density in western Oromia, Ethiopia. Asian J. Plant Sci. 2005, 4, 458-465.

15. Hillocks, R.J.; Madata, C.S.; Chirwa, R.; Minja, E.M.; Msolla, S. Phaseolus bean improvement in Tanzania, 1959-2005. Euphytica 2006, 150, 215-231. [CrossRef]

16. Funakawa, S.; Yoshida, H.; Watanabe, T.; Sugihara, S.; Kosaki, T. Soil Fertility Status and Its Determining Factors in Tanzania. In Soil Health Land Use Management; InTech - Open Access Publisher: Rijeka, Croatia, 2012; pp. 1-16.

17. Ronner, E.; Descheemaeker, K.; Almekinders, C.J.M.; Ebanyat, P.; Giller, K.E. Farmers' use and adaptation of improved climbing bean production practices in the highlands of Uganda. Agric. Ecosyst. Environ. 2018, 261, 186-200. [CrossRef]

18. Nassary, E.K.; Baijukya, F.; Ndakidemi, P.A. Sustainable intensification of grain legumes optimizes food security on smallholder farms in sub-Saharan Africa-A review. Intl. J. Agric. Biol. 2020, 23, $25-41$.

19. Keba, H.A. Adaptability evaluation of common bean (Phaseolus vulgaris L.) genotypes at western Ethiopia. Adv. Crop Sci. Technol. 2018, 6, 360. [CrossRef]

20. Tittonell, P.; Shepherd, K.D.; Vanlauwe, B.; Giller, K.E. Unravelling the effects of soil and crop management on maize productivity in smallholder agricultural systems of western Kenya-An application of classification and regression tree analysis. Agric. Ecosys. Environ. 2008, 123, 137-150. [CrossRef]

21. FAOSTAT. FAO Statistics Online Database. Production/Crops—'Beans, Dry', Year 2014. Food and Agriculture Organization. 2014. Available online: http:/faostat3.fao.org/home/E (accessed on 10 February 2016).

22. Nassary, E.K.; Baijukya, F.; Ndakidemi, P.A. Productivity of intercropping with maize and common bean over five cropping seasons on smallholder farms of Tanzania. Europ. J. Agron. 2020, 113, 125964. [CrossRef]

23. Venance, S.K.; Mshenga, P.; Birachi, E.A. Factors influencing on-farm common bean profitability, the case of smallholder bean farmers in Babati District, Tanzania. J. Econ. Sustain. Dev. 2016, 7, 196-201.

24. Ndakidemi, P.A.; Dakora, F.D.; Nkonya, E.M.; Ringo, D.; Mansoor, H. Yield and economic benefits of common bean (Phaseolus vulgaris) and soybean (Glycine max) inoculation in northern Tanzania. Australian J. Exp. Agric. 2006, 46, 571-577. [CrossRef]

25. Xavery, P.; Kalyebara, R.; Kasambala, S.; Ngulu, F. The Impact of Improved Bean Production Technologies in Northern and North Western Tanzania; Occasional Publication Series No. 43; Pan African Bean Research Alliance, CIAT Africa Region: Kampala, Uganda; Selian Agricultural Research Institute: Arusha, Tanzania, 2006.

26. Baijukya, F.; Wairegi, L.; Giller, K.E.; Zingore, S.; Chikowo, R.; Mapfumo, P. Maize-Legume Cropping Guide; Africa Soil Health Consortium: Nairobi, Kenya, (C) CAB International; 2016; Available online: http//africasoilhealth.cabi.org/wpcms/wp-content/uploads/2017/05/ASHC-English-Maize-A5-colourlowres.pdf (accessed on 12 September 2018).

27. Ronner, E.; Giller, K.E. Background Information on Agronomy, Farming Systems and Ongoing Projects on Grain Legumes in Tanzania; Wageningen, the Netherlands. 2013, p. 3. Available online: http//www.N2Africa. org (accessed on 18 July 2017).

28. Mutungamiri, A.; Mariga, I.K.; Chivhinge, A.O. Evaluation of maize (Zea mays L.) cultivars and density for dryland maize-bean intercropping. Trop. Agric. 2001, 78, 8-12.

29. Chipomho, J.; Mapope, N.; Masuka, B.; Ngezimana, W.; Chipomho, C. The influence of cropping systems and maize-bean intercrop spatial patterns on companion crop yield, weed density and biomass. Intl. J. Agric. Crop Sci. 2015, 8, 697-705.

30. Franke, A.C.; Baijukya, F.; Kantengwa, S.; Reckling, M.; Vanlauwe, B.; Giller, K.E. Poor farmers-Poor yields, socio-economic, soil fertility and crop management indicators affecting climbing bean productivity in northern Rwanda. Exp. Agric. 2016. [CrossRef]

31. Hardarson, G.; Bliss, F.A.; Cigales-Rivero, M.R.; Henson, R.A.; Kipe-Nolt, J.A.; Longeri, L.; Manrique, A.; Pena-Cabriales, J.J.; Pereira, P.A.A.; Sanabria, C.A.; et al. Genotypic variation in biological nitrogen fixation by common bean. Plant Soil 1993, 152, 59-70. [CrossRef]

32. Graham, P.H.; Vance, C.P. Legumes, Importance and constraints to greater use. Plant Physiol. 2003, 131, 872-877. [CrossRef]

33. Kermah, M.; Franke, A.C.; Adjei-Nsiah, S.; Ahiabor, B.D.K.; Abaidoo, R.C.; Giller, K.E. Legume-maize rotation or relay? Options for ecological intensification of smallholder farms in the Guinea savanna of northern Ghana. Cambridge University Press 2018. Exp. Agric. 2018, 1-19. [CrossRef] 
34. Mowo, J.G.; Janssen, B.H.; Oenema, O.; German, L.A.; Mrema, J.P.; Shemdoe, R.S. Soil fertility evaluation and management by smallholder farmer communities in northern Tanzania. Agric. Ecosys. Environ. 2006, 116, 47-59. [CrossRef]

35. Iannetta, P.P.M.; Begg, G.; James, E.K.; Smith, B.; Davies, C.; Karley, A.; Lopez Del Egido, L.; Hawes, C.; Young, M.; Ramsay, G.; et al. Sustainable intensification, a pivotal role for legume supported crop systems. Asp. Appl. Biol. 2013, 121, 73-82.

36. Vanlauwe, B.; Coyne, D.; Gockowski, J.; Hauser, S.; Huising, J.; Masso, C.; Nziguheba, G.; Schut, M.; van Asten, P. Sustainable intensification and the African smallholder farmer. Curr. Opin. Environ. Sustain. 2014, 8, 15-22. [CrossRef]

37. Rusinamhodzi, L.; Corbeels, M.; Nyamangara, J.; Giller, K.E. Maize-grain legume intercropping as an attractive option for ecological intensification that reduces climatic risk for smallholder farmers in central Mozambique. Field Crops Res. 2012, 136, 12-22. [CrossRef]

38. Kermah, M.; Franke, A.C.; Adjei-Nsiah, S.; Ahiabor, B.D.K.; Abaidoo, R.C.; Giller, K.E. Maize-grain legume intercropping for enhanced resource use efficiency and crop productivity in the Guinea savanna of northern Ghana. Field Crops Res. 2017, 213, 38-50. [CrossRef]

39. Lithourgidis, A.S.; Dordas, C.A.; Damalas, C.A.; Vlachostergios, D.N. Annual intercrops, an alternative pathway for sustainable agriculture. Aust. J. Crop Sci. 2011, 5, 396-410.

40. Hauggaard-Nielsen, H.; Jørnsgaard, B.; Kinane, J.; Jensen, E.S. Grain legume-cereal intercropping, The practical application of diversity, competition and facilitation in arable and organic cropping systems. Renew. Agric. Food Syst. 2001, 23, 3-12. [CrossRef]

41. Brooker, R.W.; Bennett, A.E.; Cong, W.-F.; Daniell, T.J.; George, T.S.; Hallett, P.D.; Hawes, C.; Iannetta, P.P.M.; Jones, H.G.; Karley, A.J.; et al. Improving intercropping, a synthesis of research in agronomy, plant physiology and ecology. New Phytol. 2015, 206, 107-117. [CrossRef]

42. Hai District Profile; Hai District Socio-Economic Profile. A Joint Publication by Hai District and Kilimanjaro Region; Hai District Report; Hai District Profile, Hai District Socio-Economic Profile: Moshi, Tanzania, 2011; p. 53.

43. Mowo, J.G.; Floor, J.; Kaihura, F.B.S.; Magoggo, J.P. Review of Fertilizer Recommendations in Tanzania, Part 2. National Soil Services Report F9; National Service Soil Fertility Report F9; ARI-Mlingano: Tanga, Tanzania, 1993; p. 116. Available online: http://library.wur.nl/WebQuery/file/isric/fulltext/isricu_i13556_001.pdf (accessed on 12 January 2015).

44. Willey, R.W. Intercropping: Its importance and research needs. Competition and yield advantage. Field Crops Res. 1979, 32, 1-10.

45. O'Leary, N.; Smith, E. Uncovering corn adaptation to intercrop with bean by selecting for system yield in the intercrop environment. J. Sustain. Agric. 2004, 24, 109-121. [CrossRef]

46. Matusso, J.M.M.; Mugwe, J.N.; Mucheru-Muna, M. Effects of different maize (Zea mays L.)—Soybean (Glycine $\max (\mathrm{L}$.$) Merill) intercropping patterns on yields, light interception and leaf area index in Embu West and$ Tigania East sub counties, Kenya. Academic Res. J. Agric. Sci. Res. 2014, 2, 6-21.

47. Mucheru-Muna, M.; Mugendi, D.N.; Pypers, P.; Mugwe, J.; Vanlauwe, B.; Merckx, R.; Kungu, J.B. Increasing productivity through maize-legume intercropping in Central Kenya. In Innovations as Key to the Green Revolution in Africa, Exploring the Scientific Facts; Bationo, A., Waswa, B., Okeyo, J.M., Maina, F., Kihara, J., Eds.; Springer Science \& Business Media B.V., Springer Dordrecht Heidelberg: London, UK, 2011; pp. 843-858.

48. Karuma, A.N.; Gachene, C.K.K.; Gicheru, P.T.; Mtakwa, P.W.; Amuri, N. Effects of tillage and cropping systems on maize and beans yield and selected yield components in a semi-arid area of Kenya. Trop. Subtrop. Agroecosys. 2016, 19, 167-179.

49. Mekbib, F. Yield stability in common bean (Phaseolus vulgaris L.) genotypes. Euphytica 2003, 130, 147-153. [CrossRef]

50. Zhang, F.; Shen, J.; Zhang, J.; Zuo, Y.; Li, L.; Chen, X. Rhizosphere processes and management for improving nutrient use efficiency and crop productivity, implications for China. Adv. Agron. 2010, 107, 1-32.

51. Dotaniya, M.L.; Prasad, D.; Meena, H.M.; Jajoria, D.K.; Narolia, G.P.; Pingoliya, K.K.; Meena, O.P.; Kumar, K.; Meena, B.P.; Ram, A.; et al. Influence of phytosiderophore on iron and zinc uptake and rhizospheric microbial activity. Afr. J. Microbiol. Res. 2013, 51, 5781-5788. 
52. Atuahene-Amankwa, G.; Falk, D.E.; Beattie, A.D.; Michaels, T.E. Early generation testing of common bean (Phaseolus vulgaris L.) populations in sole crop and in maize/bean intercrop. Can. J. Plant Sci. 1998, 78, 583-588. [CrossRef]

53. Mebrahtu, T.; Andebrhan, T.; Mohamed, A. Environmental effects on yield and agronomic traits of common bean (Phaseolus vulgaris L.). Va. J. Sci. 2001, 52,1.

54. Woolley, J.N.; Rodriguez, W. Cultivar $\times$ cropping system interactions in relay and row intercropping of bush beans with different maize plant types. Exp. Agric. 1987, 23, 181-192. [CrossRef]

55. Vendelbo, N.M.; Thomma, B.; Baijukya, F.; Giller, K.E. Effect of cropping system design on severity of biotic stresses in common bean (Phaseolus vulgaris L.) and maize (Zea mays L.) in Northern Tanzania. In Master Internship Plant Sciences; Wageningen University and Research: Wageningen, The Netherlands, 2017; p. 38.

56. Alemayehu, D.; Shumi, D.; Afeta, T. Effect of variety and time of intercropping of common bean (Phaseolus vulgaris L.) with maize (Zea mays L.) on yield components and yields of associated crops and productivity of the system at mid-land of Guji, Southern Ethiopia. Adv. Crop Sci. Tech. 2018, 6, 324. [CrossRef]

57. Saban, Y.; Mehmt, A.; Mustafa, E. Identification of advantages of maize legume intercropping over solitary cropping through competition indices in the east mediterranean region. Turk. J. Agric. 2007, 32, 111-119.

(C) 2020 by the authors. Licensee MDPI, Basel, Switzerland. This article is an open access article distributed under the terms and conditions of the Creative Commons Attribution (CC BY) license (http://creativecommons.org/licenses/by/4.0/). 